Arab Univ. J. Agric. Sci., Ain Shams Univ., Cairo, 14(2), 861-870, 2006

\title{
MOLLUSCICIDAL EFFICACY AND TOXICITY OF SOME PESTICIDES UNDER LABORATORY AND FIELD CONDITIONS
}

\section{[56]}

\author{
Abdel-Halim $^{1}$, K.Y.; R.K. Abou-El Khear ${ }^{2}$ and A.A. Hussein ${ }^{1}$
}

\begin{abstract}
Laboratory and field trials were carried out at Koom Hamada district and Etay El-baroud research station during 2004/ 2005 season to clarify the molluscicidal activities of the following: indoxacarb, lufenuron, Bacillus thurringiensis, kurestaci (Bt.) and methomyl against glassy clover snails Monacha cartusiana (Müler). Results indicated that all tested pesticides decreased snails population compared with control. Under the field conditions, the efficiency of the tested compounds were 98.0, 93.4, 93 and 71.58\% for methomyl, lufenuron, indoxacarb and Bt. after 5, 6, 13, and 28 days of treatment, respectively. Moreover the effect of $\mathrm{LC}_{50}$ and 0.5 $\mathrm{LC}_{50}$ of these compounds were investigated on some biochemical parameters in vivo. The activities of acetylcholinestrase (AChE), alanine aminotransferases (ALT), aspartate aminotransferases (AST) and protein contents at different time intervals were evaluated. The specific activity of AChE reached 0.009, 0.002, 0.006 and 0.001 $\mu \mathrm{mole} / \mathrm{mg}$ protein/ min for indoxacarb, lufenuron, Bt. and methomyl, respectively, after one day of treatment with ( $\mathrm{LC}_{50}$ for each compound). In general, Bt. and indoxacarb caused slight inhibition on AChE enzyme. All treatments decreased ALT and AST enzyme activity in the tested animals. However, Bt. Showed slight effect on the activity of aminotransferases enzymes.
\end{abstract}

Keywords: Snails, Molluscs, Pesticides, Toxicity, Enzymes.

\section{INTRODUCTION}

Mollusks are a large and diverse group of animals distributed worldwide (El-Okda, 1980; Godan, 1983 and Nakhla et al 1993). Terrestrial gastropods (mollusks: snails and slugs) are being abundantly distributed in the North coast, new rec- laimed lands and addition to delta region of Egypt (Kasaab and Daoud, 1964); (El-Okda and Khalil, 1981) and (AbouBaker, 1997). Also, snails are becoming serious agricultural animal pests in Egypt, especially in the Northern coastal areas. Their damage to ornamental plants resembles that done by caterpillars or

1- Central Agric Pesticide Laboratory (CAPL) ARC, Etay El-Baroud, Egypt

2- Plant Protection Res. Ins. , Agric Res. Center (ARC), International Potato Center (CIP), Ministry of Agriculture, Kafr El-Zayat, Egypt

(Received April 18, 2006)

(Accepted July 24, 2006) 
wireworms. The brown garden snail ( $\mathrm{He}$ lix aspersa), is the common snail causing problems in California gardens; it was introduced from France during the 1850s for use as food. Snails and slugs move by gliding along on a muscular "foot". Snails and slugs feed on a variety of living plants as well as on decaying plant matter. On plants, they chew irregular holes with smooth edges in leaves and can clip succulent plant parts (Flint, 1998). They can also chew fruit and young plant bark. A good snail and slug management program relies on a combination of methods. The first step is eliminate, all places where snails or slugs can hide during the day. Boards, stones, debris, weedy areas around tree trunks, leafy branches growing close to the ground, and dense ground covers such as ivy are ideal sheltering spots safe (Salagado, 1990). Synthetic molluscicides are still considered the most effective measures for the control of snails. Lufenuron is a new insecticide being effective against resistant pests to organophosphates and pyrthroides. It was soft on adult beneficial and predatory mites, safe on a wide range of crops and suitable for integrated pest management (Harder et al 1996). One of the most promising biological control approach that has received attention of many scientists is the development of Bacillus thuringiensis (Bt.) toxins as insecticides (Belfore et al 1994). Diple $2 \mathrm{X}$ is one of the biological insecticides containing proteins that are highly toxic to insects. Indoxacarb is the common name proposed for the $\mathrm{S}$-isomer of oxadiazine derivative, which is insecticidal active isomer. This compound represents a new class of compounds has broadspectrum insecticidal activity and yet be environmentally safe (Salagado, 1990).
The present study was aimed to evaluate the efficacy of some safe pesticides such as indoxacarb, Bacillus thuringiengsis (Bt.) and lufenuron as molluscicides compared with methomyl under field conditions, and examined their effects on some biochemical parameters in the laboratory.

\section{MATERIAL AND METHODS}

\section{I- Field Studies}

The field study was conducted in clover fields at Koom Hamada district, El-Behera governorate during May, 2005. The treatments were done with $0.5 \mathrm{LC}_{50}$ and $\mathrm{LC}_{50}$ which cited from Abou- El Khear et al (2005). The $\mathrm{LC}_{50}$ values were $6.7,6.4,7.0$, and $5.9 \times 10^{4} \mathrm{ppm}$ for indoxacarb (Avanet ${ }^{\circledR} \quad 15 \%$ SC) methyl (s)-N- [7-chloro-2, 3, 4, a, 5-tetrahydro4a (methoxy carbonyl) indeno [1,2-e] [1, 3 , 4] oxadiazin-2-yl carbonyl]-4(trifloromethoxy) carbonilate; lufenuron (Match $^{\circledR}$ 5\% EC): N-[[[2, 5-dichlro-4-(1, $1,2,3,3,3, \quad$-hexafluro-propoxy)-(phenyl] amino] carbonyl]-2, 6-difluorobe-zamide (CA); Dipel ${ }^{\circledR}-2 \mathrm{X} 10.3 \%$ WP: Bacillus thuringeinsis, kurestaci. and methomyl (Lannate $^{\circledR}$ 90\% SP): S-methyl-N- (methylcarbamoyl) oxyl- thioacetimidate, respectively. The experiments were carried out in plots of $1 / 4$ feddan each $\left(1000 \mathrm{~m}^{2}\right)$. Each treatment was replicated five times in random blocks. Bait were distributed before sunset using twelve bait stations in different areas of the plot. Wheat bran was kept in bait stations for three days, and then the poisoned baits were added in $200 \mathrm{gm}$ each. The bait stations were inspected and replenished on each subsequent two days until the cessation of the snails' activity, nearly for one 
month. Daily bait consumption and dead animals were counted and removed from each plot. Daily observation and snails traps in this area showed that, Monacha cartusiana was the most common and important species. Mortality percentage was calculated and the molluscicidal potencyexpressed as population reduction was measured for all tested compounds according to Henderson and Tilton equation (1955):

\section{Reduction \% \\ $=1-\{$ No. of control before baiting No. of control after baiting}

\section{No. of treatment after baiting\} No. of treatment before baiting}

\section{II- Biochemical Studies}

The glassy clover snails Monacha cartusiana (Müller) were collected from clover fields in 2004/2005 season from Koom Hamada district and transferred to laboratories at Etay El-Broud Research Station, El-Behera governorate. The shell diameter of adult snails was measured at average $1.6 \mathrm{~cm}$. They were acclimatized for a week under laboratory conditions and fed on lettuce (Lactuca sativa) ad lib. Toxic white bran baits were prepared containing each $\mathrm{LC}_{50}$ or $0.5 \mathrm{LC}_{50}$ values of tested pesticides. The bait consisted of grain bran: molasses: blue dye with the ratio 8: 1: 1, respectively, (WHO, 1961). Baits were distributed in three replicates and 15 healthy animals were used in each replicate. In the case of control, pesticides were substituted with distilled water. Replicates were kept under laboratory conditions and suitable humidity required for snail activity. The dead animals were discarded, while the healthy adults were taken at different time intervals, i.e. 1, 3, 5 , and 7 days of treatment. The soft tissues were weighed at average $(0.86 \mathrm{gm})$, pooled, and homogenized as 1: $10(\mathrm{w} / \mathrm{v})$ in buffer phosphate $(0.1 \mathrm{M}) \mathrm{PH}$ 7.0. The homogenate was centrifuged at $5000 \mathrm{rpm}$ for $20 \mathrm{~min}$ under cooling. The supernatant was decanted and frozen at $-20{ }^{\circ} \mathrm{C}$ until used as enzymes source. Activities of some enzymes were measured such as alanine aminotransferases (ALT), aspartate aminotransferases (AST) according to Retman and Frankel method (1957). Additionally, acetylcholiesterase (AChE) activity was measured according to Ellman et al (1961) and its specific activity was expressed as $\mu$ mole substrate hydrolyzed $/ \mathrm{mg}$ protein $/ \mathrm{min}$. Total protein was measured according to Lowry et al (1951).

\section{Statistical Analysis}

In filed treatments, analysis of variance was used to compare means among treatment. The least square means were compared for significant differences between treatments using student- New man- Keals test (Sokel and Rohlf, 1969). While, in biochemical studies all data were calculated as $\mathrm{X} \pm$ S.E. and comparison between two groups was performed by student t-test (Motulesky, 1987). Pvalue of 0.05 was considered significant.

\section{RESULTS AND DISCUSSION}

\section{Molluscicidal activities of tested in- secticides}

The Survey and observation of the studied area showed that, glassy clover snails Helix aspersa (Müller) is the common species snails on winter crops. The 
efficacy of tested pesticides under the field conditions was evaluated as snails' population reduction, bait consumption, days of pest control and the required poison baits ( $\mathrm{Kg} / \mathrm{feddan})$. The results in Table (1) indicated that, methomyl and lufenuron were the most effective against brown snails causing (96.96 and 98.03\%) and $(85.44$ and $94.66 \%)$ reduction in population for $0.5 \mathrm{LC} 50$ and LC50, respectively. The population reduction by indoxacarb reached 79.02 and $93.33 \%$ with 0.5 LC50 and LC50, respectively. The lowest effective pesticide as molluscicide was Diple-2X, where the population reduction of snails reached 45.82 and $71.58 \%$ with the same concentrations, respectively.

Concerning the amounts of consumed baits, it was found that, Bt. bait exhibited the highest consumption by snails $(7.6 \mathrm{Kg}$ /feddan). While, the low consumptions were $2.5,4.0$, and $5.5 \mathrm{Kg} /$ feddan for methomyl, lufenuron, and indoxacarb, respectively. On the other hand, the periods required to achieve successful control of the snails were $5,12,14$, and 28 days for methomyl, lufenuron, indoxacarb and Diple-2X, respectively.

Generally, lufenuron and indoxacarb showed high molluscicidal effect against clover snails, which considered an important pest on most field crops, under field conditions compared with methomyl, in addition to other positive properties of the compounds low toxicity to non-target organisms and short persistence in the environment (Salagado, 1990; Harder, et al 1996 and Pluschkell et al 1998). Abou-El Khear et al (2005) found the same results under laboratory conditions. These results agree with the findings by Hussien (2003) who indicated that, methomyl was more effective as mollusci- cidal compound using topical application and poisoned food techniques than indoxacarb. Abou-Baker (1997) illustrated that, the chemical control is the most powerful tool available for controlling snails. Zedan et al (1999) found that, bacterial formulation was the most effective against land snails compared with methomyl.

\section{Toxicolgical activities of tested insec- ticides}

Data on the Aspartate aminotransferases (AST), alanine aminotransferases (ALT), acetylcholinesteras activities and protein concentration in animals treated with $0.5 \mathrm{LC}_{50}$ and $\mathrm{LC}_{50}$ of the tested pesticides at different time intervals are shown in Tables (2 and 3). AST activity was reduced by 85.4 and $80.6 \%$ (Diple2X); 69.6 and $53.3 \%$ (indoxacarb); 79.8 and $72.6 \%$ (lufenuron) and 63.6 and $67.7 \%$ ( methomyl) for animals treated with $0.5 \mathrm{LC}_{50}$ and $\mathrm{LC}_{50}$, respectively, after three days of treatment. Alanine aminotransferase was also significantly reduced compared with control animals. The inhibitory effects by $0.5 \mathrm{LC}_{50}$ and $\mathrm{LC}_{50}$ for methomyl, lufenuron, indoxacarb, and Diple-2X on the AChE activity of snails are shown in Table (3). The results indicated that, the highest inhibitory effect against $\mathrm{AChE}$ enzyme activity of treated animals was occurred with $\mathrm{LC}_{50}$ of methomyl. The specific activity of $\mathrm{AChE}$ was expressed as $\mu \mathrm{mole} / \mathrm{mg}$ protein/min which accounted for 0.004 , $0.004,0.002$, and $0.001 \mu \mathrm{mole} / \mathrm{mg}$ protein/min for Diple-2X, indoxacarb, lufenuron, and methomyl, respectively. Slight inhibition in AChE enzyme activity was done with lufenuron and Diple-2X treatments. In addition, the protein 
866

Abdel-Halim; Abou-El Khear and Hussein

Table 2. Effect of tested pesticides against alanine aminotransferases (ALT), aspartate aminotransferases (AST) activities of glassy clover snails Monacha cartusiana (Müler) at different time intervals

\begin{tabular}{|c|c|c|c|c|c|c|}
\hline \multirow[b]{2}{*}{ Treatment } & \multicolumn{6}{|c|}{ Enzyme Activity } \\
\hline & Dose & $\begin{array}{c}\text { Time } \\
\text { interval } \\
\text { (day) }\end{array}$ & $\begin{array}{c}\text { AST } \\
(\mathrm{U} / 1)\end{array}$ & $\begin{array}{c}\% \\
\text { of } \\
\text { Control }\end{array}$ & $\begin{array}{c}\text { ALT } \\
(\mathrm{U} / 1)\end{array}$ & $\begin{array}{c}\% \\
\text { of } \\
\text { Control }\end{array}$ \\
\hline \multirow{4}{*}{ Control } & \multirow{4}{*}{ - } & 1 & $47.3 \pm 7.5$ & 100 & $18.7 \pm 2.4$ & 100 \\
\hline & & 3 & $41.3 \pm 3.2$ & 100 & $28.8 \pm 4.3$ & 100 \\
\hline & & 5 & $43.0 \pm 3.1$ & 100 & $26.8 \pm 4.6$ & 100 \\
\hline & & 7 & $42.3 \pm 4.2$ & 100 & $22.5 \pm 2.1$ & 100 \\
\hline \multirow{8}{*}{$B t$} & \multirow{4}{*}{$0.5 \mathrm{LC}_{50}$} & 1 & $25.7 \pm 4.6 * *$ & 54.3 & $19.0 \pm 2.5$ & 101.6 \\
\hline & & 3 & $35.0 \pm 4.8 * *$ & 85.4 & $21.8 \pm 3.1 * *$ & 75.6 \\
\hline & & 5 & $5.8 \pm 2.3 * *$ & 13.5 & $12.0 \pm 3.2 * *$ & 44.7 \\
\hline & & 7 & $7.7 \pm 1.3 * *$ & 18.2 & $14.3 \pm 2.6^{* *}$ & 63.5 \\
\hline & \multirow{4}{*}{$\mathrm{LC}_{50}$} & 1 & $26.7 \pm 3.6 * *$ & 56.4 & $13.9 \pm 3.4 * *$ & 74.2 \\
\hline & & 3 & $33.3 \pm 2.5 * *$ & 80.6 & $23.8 \pm 4.1 * *$ & 82.3 \\
\hline & & 5 & $13.0 \pm 1.3 * *$ & 30.2 & $18.7 \pm 3.6^{* *}$ & 70.0 \\
\hline & & 7 & $7.73 \pm 2.1 * *$ & 33.0 & $12.1 \pm 3.2 * *$ & 53.8 \\
\hline \multirow{8}{*}{ indoxacarb } & \multirow{4}{*}{$0.5 \mathrm{LC}_{50}$} & 1 & $22.0 \pm 3.5 * *$ & 46.5 & $10.7 \pm 3.5 * *$ & 57.2 \\
\hline & & 3 & $28.7 \pm 3.4 * *$ & 96.6 & $12.1 \pm 1.3 * *$ & 42.1 \\
\hline & & 5 & $5.7 \pm 1.2 * *$ & 13.3 & $13.4 \pm 2.3 * *$ & 50.0 \\
\hline & & 7 & $6.7 \pm 1.4 * *$ & 28.7 & $22.2 \pm 1.8^{* *}$ & 98.7 \\
\hline & \multirow{4}{*}{$\mathrm{LC}_{50}$} & 1 & $33.0 \pm 5.2 * *$ & 69.7 & $9.1 \pm 2.1 * *$ & 48.7 \\
\hline & & 3 & $22.0 \pm 1.2 * *$ & 53.3 & $15.3 \pm 2.9 * *$ & 56.8 \\
\hline & & 5 & $5.47 \pm 1.1 * *$ & 12.7 & $12.1 \pm 3.7 * *$ & 42.5 \\
\hline & & 7 & $7.47 \pm 1.4 * *$ & 32.1 & $14.0 \pm 3.8^{* *}$ & 62.2 \\
\hline \multirow{8}{*}{ lufenuron } & \multirow{4}{*}{$0.5 \mathrm{LC}_{50}$} & 1 & $24.3 \pm 2.2 *$ & 51.3 & $13.2 \pm 2.4 * *$ & 70.5 \\
\hline & & 3 & $34.3 \pm 3.2 *$ & 79.8 & $18.3 \pm 2.4 * *$ & 63.6 \\
\hline & & 5 & $31.0 \pm 3.5$ & 75.1 & $16.9 \pm 1.8^{* *}$ & 63.3 \\
\hline & & 7 & $11.0 \pm 1.3 * *$ & 47.2 & $19.6 \pm 3.7$ & 87.5 \\
\hline & \multirow{4}{*}{$\mathrm{LC}_{50}$} & 1 & $16.0 \pm 0.0 * *$ & 33.8 & $12.9 \pm 1.7 * *$ & 68.9 \\
\hline & & 3 & $30.0 \pm 0.8^{*}$ & 72.6 & $23.1 \pm 1.9 *$ & 80.2 \\
\hline & & 5 & $24.3 \pm 0.7 * *$ & 56.5 & $20.2 \pm 2.3 *$ & 75.3 \\
\hline & & 7 & $15.0 \pm 0.2 * *$ & 64.3 & $22.1 \pm 2.6$ & 98.2 \\
\hline \multirow{8}{*}{ methomyl } & \multirow{4}{*}{$0.5 \mathrm{LC}_{50}$} & 1 & $24.3 \pm 2.3 * *$ & 51.4 & $19.3 \pm 3.1$ & 103.2 \\
\hline & & 3 & $26.3 \pm 3.6^{* *}$ & 63.6 & $14.2 \pm 1.6^{* *}$ & 49.4 \\
\hline & & 5 & $4.5 \pm 1.1 * *$ & 10.4 & $16.5 \pm 2.9 * *$ & 61.2 \\
\hline & & 7 & $6.7 \pm 1.4 * *$ & 28.8 & $14.9 \pm 2.9 * *$ & 66.3 \\
\hline & \multirow{4}{*}{$\mathrm{LC}_{50}$} & 1 & $27.3 \pm 7.5 * *$ & 57.6 & $14.4 \pm 2.4 * *$ & 48.3 \\
\hline & & 3 & $31.6 \pm 2.2 * *$ & 76.7 & $17.0 \pm 3.5$ & 93.7 \\
\hline & & 5 & $11.4 \pm 1.3^{* *}$ & 26.5 & $14.0 \pm 1.8^{* *}$ & 52.4 \\
\hline & & 7 & $3.2 \pm 0.0 * *$ & 13.7 & $22.4 \pm 2.3$ & 100 \\
\hline
\end{tabular}

Each value is the mean of three replicates $\pm \mathrm{S}$. E.

* Significant at $0.05 \quad * *$ Significant at 0.01

Arab Univ. J. Agric. Sci., 14(2), 2006 
Table 3. Effect of tested pesticides against acetyl cholinesterase (AChE) activity and total protein of glassy clover snails Monacha cartusiana (Müller) at different time intervals

\begin{tabular}{|c|c|c|c|c|c|c|}
\hline \multirow[b]{2}{*}{ Treatment } & \multicolumn{6}{|c|}{ Enzyme Activity } \\
\hline & Dose & $\begin{array}{c}\text { Time } \\
\text { interval } \\
\text { (day) }\end{array}$ & $\begin{array}{c}\text { AChE } \\
\text { Activity } \\
(\mu \mathrm{mole} / \mathrm{mg} \\
\text { protein } / \mathrm{min})\end{array}$ & $\begin{array}{c}\% \\
\text { of } \\
\text { Control }\end{array}$ & $\begin{array}{l}\text { Total protein } \\
(\mathrm{mg} / \mathrm{ml})\end{array}$ & $\begin{array}{c}\% \\
\text { of } \\
\text { Control }\end{array}$ \\
\hline \multirow{4}{*}{ Control } & \multirow[b]{4}{*}{-} & 1 & $0.002 \pm 0.0$ & 100 & $120.6 \pm 2.5$ & 100 \\
\hline & & 3 & $0.004 \pm 0.0$ & 100 & $121.3 \pm 0.48$ & 100 \\
\hline & & 5 & $0.003 \pm 0.001$ & 100 & $128.6 \pm 3.8$ & 100 \\
\hline & & 7 & $0.033 \pm 0.009$ & 100 & $128.9 \pm 4.3$ & 100 \\
\hline \multirow{8}{*}{$B t$} & \multirow{4}{*}{$0.5 \mathrm{LC}_{50}$} & 1 & $0.003 \pm 0.00$ & $67.23 * *$ & $95.77 \pm 3.8 * *$ & 78.51 \\
\hline & & 3 & $0.004 \pm 0.001$ & 102.3 & $105.2 \pm 3.7 *$ & 86.65 \\
\hline & & 5 & $0.007 \pm 0.00$ & $64.69 * *$ & $96.67 \pm 2.8 * *$ & 75.00 \\
\hline & & 7 & $0.023 \pm 0.001$ & $36.20 * *$ & $10.44 \pm 100^{*}$ & 77.88 \\
\hline & \multirow{4}{*}{$\mathrm{LC}_{50}$} & 1 & $0.006 \pm 0.002$ & $47.13 * *$ & $28.00 \pm 5.6^{* *}$ & 23.33 \\
\hline & & 3 & $0.005 \pm 0.001$ & 95.83 & $77.00 \pm 4.6 * *$ & 63.63 \\
\hline & & 5 & $0.004 \pm 0.00$ & $57.24 * *$ & $68.67 \pm 1.2 * *$ & 53.42 \\
\hline & & 7 & $0.061 \pm 0.001$ & 92.19 & $97.13 \pm 2.4$ & 75.35 \\
\hline \multirow{8}{*}{ indoxacarb } & \multirow{4}{*}{$0.5 \mathrm{LC}_{50}$} & 1 & $0.002 \pm 0.00$ & $62.77 * *$ & $65.0 \pm 4.9 * *$ & 54.16 \\
\hline & & 3 & $0.005 \pm 0.001$ & $62.69 * *$ & $65.78 \pm 6.2 * *$ & 54.36 \\
\hline & & 5 & $0.012 \pm 0.002$ & 95.14 & $39.78 \pm 3.4 * *$ & 30.93 \\
\hline & & 7 & $0.012 \pm 0.003$ & $31.48 * *$ & $99.65 \pm 4.6 * *$ & 77.30 \\
\hline & \multirow{4}{*}{$\mathrm{LC}_{50}$} & 1 & $0.009 \pm 003$ & $68.98 * *$ & $66.45 \pm 3.8 * *$ & 55.09 \\
\hline & & 3 & $0.004 \pm 0.00$ & $57.71 * *$ & $59.78 \pm 5.7 * *$ & 49.27 \\
\hline & & 5 & $0.023 \pm 0.012$ & $58.06 * *$ & $44.22 \pm 3.7 * *$ & 34.46 \\
\hline & & 7 & $0.026 \pm 0.00$ & $30.63 * *$ & $76.09 \pm 1.3 * *$ & 59.03 \\
\hline \multirow{8}{*}{ lufenuron } & \multirow{4}{*}{$0.5 \mathrm{LC}_{50}$} & 1 & $0.003 \pm 0.00$ & $69.82 * *$ & $64.33 \pm 3.9 * *$ & 53.34 \\
\hline & & 3 & $0.002 \pm 0.00$ & $28.01 * *$ & $56.33 \pm 4.6^{* *}$ & 46.42 \\
\hline & & 5 & $0.003 \pm 0.00$ & $39.64 * *$ & $55.22 \pm 4.4 * *$ & 42.9 \\
\hline & & 7 & $0.040 \pm 0.01$ & $34.25 * *$ & $82.00 \pm 5.3^{*}$ & 63.6 \\
\hline & \multirow{4}{*}{$\mathrm{LC}_{50}$} & 1 & $0.002 \pm 0.00$ & $58.87 * *$ & $73.78 \pm 5.6^{* *}$ & 61.17 \\
\hline & & 3 & $0.002 \pm 0.00$ & $33.84 * *$ & $87.78 \pm 2.5^{*}$ & 72.36 \\
\hline & & 5 & $0.003 \pm 0.00$ & $63.85 * *$ & $79.67 \pm 3.5^{* *}$ & 61.95 \\
\hline & & 7 & $0.013 \pm 0.00$ & $14.49 * *$ & $73.00 \pm 7.5^{* *}$ & 56.63 \\
\hline \multirow{8}{*}{ methomyl } & \multirow{4}{*}{$0.5 \mathrm{LC}_{50}$} & 1 & $0.002 \pm 0.00$ & $51.74 * *$ & $81.78 \pm 3.2 * *$ & 67.17 \\
\hline & & 3 & $0.004 \pm 0.00$ & $63.30 * *$ & $76.67 \pm 2.7 * *$ & 61.25 \\
\hline & & 5 & $0.006 \pm 0.00$ & $61.43 * *$ & $53.33 \pm 2.5 * *$ & 41.46 \\
\hline & & 7 & $0.028 \pm 0.01$ & $23.53 * *$ & $53.89 \pm 1.3 * *$ & 41.46 \\
\hline & \multirow{4}{*}{$\mathrm{LC}_{50}$} & 1 & $0.001 \pm 0.00$ & $31.98 * *$ & $74.33 \pm 4.6^{* *}$ & 61.63 \\
\hline & & 3 & $0.003 \pm 0.00$ & $60.75 * *$ & $57.67 \pm 5.7$ & 55.88 \\
\hline & & 5 & $0.004 \pm 0.00$ & $47.00 * *$ & $31.22 \pm 3.1 * *$ & 47.60 \\
\hline & & 7 & $0.042 \pm 0.01$ & $31.55^{* *}$ & $46.56 \pm 1.1 * *$ & 36.20 \\
\hline
\end{tabular}

Each value is the mean of three replicates \pm S.E.

* Significant at $0.05 \quad * *$ Significant at 0.01 
content was significantly decreased after methomyl, lufenuron, indoxacarb, and Diple-2X treatment. The highest reduction was recorded in the animals treated with the high concentration $\left(\mathrm{LC}_{50}\right)$ of methomyl. AChE was more vulnerable proteins than other enzyme system especially against methomyl that attributed to its toxic effect. Elevation of AST and ALT had been reported in pesticide treatments (El-Wakil et al 1992; Radwan et al 1992; Radwan et al 1993; and Mohamed, 1995). The possible mechanisms involved in the elevation of AST and ALT activities observed in the present study may be based on tissue damage, increased synthesis or decreased catabolism of both enzymes (Todior and Van-Heemastra, 1980). On the other hand, the decreased activity of AST and ALT may be due to rather leakage of the enzyme into extra cellular compartments or to actual enzyme inhibition by tested pesticides (Abou-Baker, 1997; Abdalla et al 1998 and Hussein, 2003).

\section{REFRENCES}

Abdallah, E.M.A.; F.A. Kassem; H.B. El-Wakil and Y. Abou-Baker (1998). Molluscicidal potentially of several pesticides against Eobania vermiculata and Theba pisena terrestrial snails. Annals Agric. Sci. 17 (1): 263-276.

Abou-Baker, Y.A. (1997). Toxicological and Environmental Studies on Some Terrestrial Gastropods. pp. 113-122. M. Sc. Thesis, Faculty of Agric. Univ. of Alexandria, Egypt.

Abou-El Khear, R.K.; Kh.Y. AbdelHalim and A.A. Hussien (2005). Molluscicidal efficiency of some pesticides against Helix aspersa land snails under laboratory conditions. J. Agric. Sci. Mansoura Univ., 30(2): 1129- 1134.

Belfore, G.J.; R.K. Vadlamudi; Y.A. Osman and L.A. Bula (1994). A specific binding protein from tenebriomolitor for the insecticidal toxin of Bacillus thuringensis subsp tendnebrionis. J. Bioch. \& Biophys. Res. Comm. 200 (1): 359-364.

Ellman, G.L.; K.D. Country; V. Anders and R.M. Featherstone (1961). A new and rapid colorimetric determination of acetylcholinesterase activity. Biochem. Pharmacol. 7: 88-95.

El-Okda, M.M.K. (1980). Land snails of economic iImportance on vegetable crops at Alexandria and Neighboring regions. Agric Res. Rev. 58 (1): 79- 86.

El-Okda, M.M.K. and K.A. Khalil (1981). Land mollusks economic pest attaching fruit orchards at Alexandria governorate. Proc. $4^{\text {th }}$ Arab Pesticides Conf. Tanta Univ., Egypt. 11: 289-302.

El- Wakil, H.B.; M.A. Radwan and K.A. Osman (1992). Interaction of Some Oxime Carbamate Pesticides with Terrestrial Helix aspersa Snail Enzyme System. Alex. Sci. Exch.13 (3): 81-99.

Flint, L. (1998). Pests of the Garden and Snail Farm: A Grower's Guide to Using Less Pesticide. $2^{\text {nd }}$ Ed, Oakland: Univ . Calf. Div., Agric. and Nat. Resources Publication 3332.

Godan, D. (1983). Pest Slugs and Snails, Biology and Control. pp. 191192. Springer Verlag: Berlin.

Harder, H.H.; S.L. Riley; S.F. Mocann and S.N. Irving (1996). Indoxacarb: A novel broad spectrum environmentally soft, insect control. Proc. Brighton. Corp Protection Conf. Pests of Diseases, Brighton, UK, pp. 449- 454.

Henderson, C.F. and W. Tilton (1955). Tests with acaricides against the brown 
wheat mite. J. Econ. Entomol. 98: 157161.

Hussien, A.A. (2003). Toxicological and Biochemical Studies on Some Economic Pests. pp. 134-163. Ph. D. Thesis, Faculty of Agric., Univ. of Alexandria, Egypt.

Kassab, A. and H. Daoud (1964). Notes on the biology of land snails of economic importance in UAR. Agric. Rev., Min. of Agric, Cairo, 42: 77-88.

Lowry, A.M.; N.J. Rosebrough; A.L. Farr and R.J. Randall (1951). Protein measurement with folin phenol reagent. J. Biol. Chem., 193: 256-275.

Mohamed, Y.M. (1995). The Toxic Action of an Insecticide; Selecron 720 EC on Biological System. pp.79-88. M.Sc., Thesis, Faculty of Agric., Cairo Univ., Egypt.

Motulesky, H.I. (1987). T-ease (tm), Ttests with ease, ISI Software, Institute for Scientific Information. Berkeley, CA.

Nakhla, J.M.; A.W. Tadros; A.A. Abdel-Hafiz and A.G. Hashem (1993). Survey and monitoring of land snails in pear orchards at the northern reclaimed lands. Alex. Sci. Exch. 14(3): 43-57.

Pluschkell, V.; A.R. Horowitz; G. Phllis and I. Ishaaya (1998). DPXMPO62 potent compound for controlling the Egyptian cotton leaf worm Spodoptera littoralis (Biosd). Pestic. Sci., 54: 85-90.

Radwan, M.A.; H.B. El-Wakil and K.A. Osman (1992). Toxicity and bio- chemical impact of certain oxime carbamate pesticides against terrestrial snails Theba pisana (Muller). J. Environ. Sci. Health, B 27 (6): 759-773.

Radwan, M.A.; K.A. Osman and A.K. Salama (1993). Biochemical response of the brown garden snail Helix aspersa to chlorfluarzuron and flufenoxuron. J. Environ. Health, B28 (3): 291 - 303.

Retman, S. and S. Frankel (1957). A colorimetric method for determination of serum glutamic oxaloacetic acid and glutamic pyruvic transaminase. Am. J. Clin. Path. 28: 56- 63.

Salagado, V.L. (1990). Mode of action of insecticidal diydro pyrazoles: selective block of impulse generation in sensory nerves. Pestic. Sci. , 23: $389-411$.

Sokel, R.R. and J.F. Rohlf (1969). Biometry. Freeman, W.H-Co Stat / ANOVA Randomized Complete Blocks. San Francisco, USA.

Todior, W.F. and E.A.H. VanHeemastra (1980). Field Studies Monitoring Exposure and Effects in The Development of Pesticides. pp. 207-213, Elsevier; Amsterdam.

WHO, (1961). Expert committee on bilharziasis, Wid. Hilth., Org. Tech. Rep. Ser. No. 214.

Zedan, H.A.; A.A. Saleh and S.M. Abdail (1999). Bacterial activity of Bacillus thuuringesis against snails-toxicological and histological studies. Proc. $2^{\text {nd }}$ Int. Conf. of Pest Control, pp. 489-497 Mansoura, Egypt. 
بحلة اتحاد الجحامعات العربية للدراسات والبحوث الزراعية ، جامعة عين شمس ، القاهرة ،14(2) ، 861-870 ، 2006 الكفاعة الابادية وسمية بعض المبيدات ضد قوقع البرسيم الزجاجي تحت الظروف الحقلية والمعملية

[56]

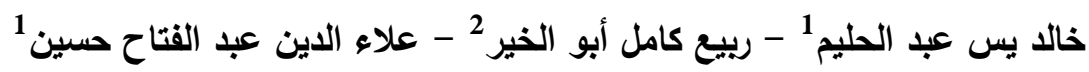

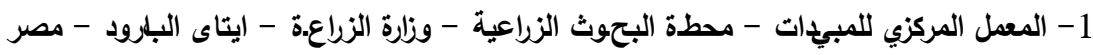

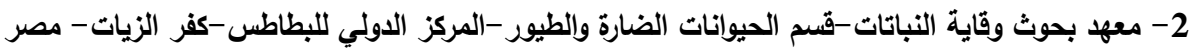

لأعلى إبادة هي ( 5 و12 و14 و28 يوما

$$
\text { على التو الي). }
$$

* كانت كمية المبيد اللازمة لتحقيق المكافحة الناجحة للقو اقع 7.6 - 5.5 - 4 - 4.2 كجم /فدان للاييل ، الافانت ، الماتش ثم اللانيت على التو الي.

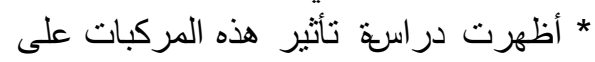

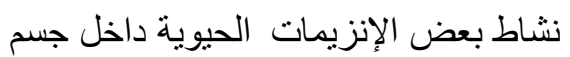

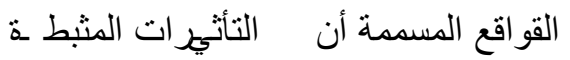

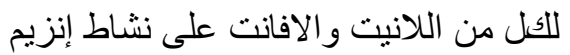

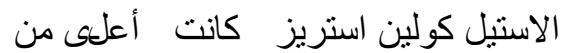

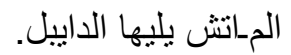

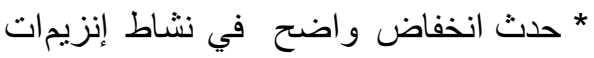
ALT, AST

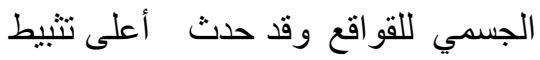

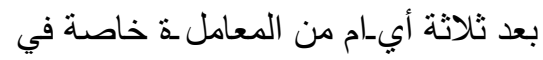
حالة استخ دام التركيز النصفى القاتل لمنل

$$
. \mathrm{LC}_{50}
$$$$
\text { أجريت هذه الدراسة تحت الظروف }
$$$$
\text { الحقلية بمركز كوم حمادة محافظة البحيرة }
$$$$
\text { ومحطة البحوث الزر اعية بايتاى البارود }
$$

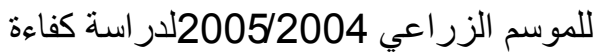
ثلاث مركبات حديثة و آمنة بيئيا من مجا ميع مختلفة هى مركب الماتش ( ليفينيرون 15

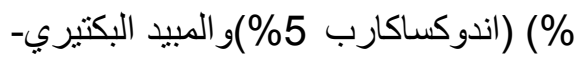

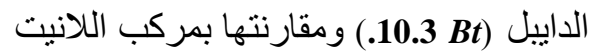

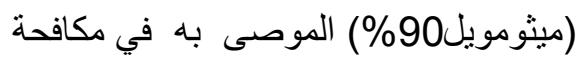
القو اقع الأرضية. تم استخدام تركزين من هذه المركبات

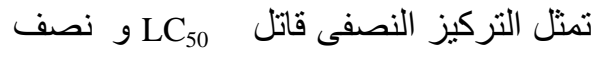
هدا التركيز 0.5 LC كطعوم سامة أظهرت نتائج الدراسات الحقلية أن:-

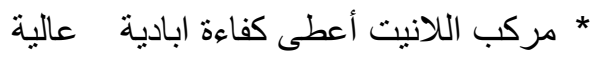
حتى 98 \%خلال خمسة أيام من المعاملة يليه مركب الماتش (93,33\%) ثم الافانت

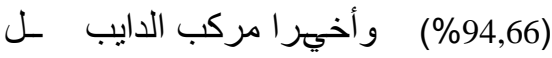
(71,58) وكانت المدة اللازمة للوصول الابب تحكيم: أ.د زيدان هندى عبد الحميد أ.د محمد عبد الهادى قنديل Arab Univ. J. Agric. Sci., 14(2), 2006 